\title{
Reform Measures for Training Mode of Applied Talents Majoring in Music in Local Undergraduate Schools
}

\author{
Zhe Guo, Yuefang Lv \\ XingTai University, Xingtai, 054001, China
}

Keywords: LOcal undergraduate schools, MUsic major, TRAIning of applied talents, REForm measures

\begin{abstract}
With the great progress of economic development, the living standard of people has improved and Chinese people start to pursue for spiritual culture. Therefore, the society has a larger and larger demand for talents majoring in music. Meanwhile, China has gradually possessed more financial resources and material resources for cultural construction. Therefore, China conforms to the development of the times and puts forward the great strategy of "powerful country in culture" so as to satisfy demands of social residents and promote the great development of Chinese cultural industry. To respond to the great call of "powerful country in culture", Chinese local undergraduate schools start to pay attention to the establishment of training mode of applied talents majoring in music.
\end{abstract}

\section{Introduction}

As an important constituent part of culture and art, music reflects the development level of cultural soft power of China. ${ }^{[1]}$ With the constant progress of the times in the current world, the times of industrial revolution has come to a close and people start to enter the times of knowledge-based economy in which people pay more attention to the pursuit for artistry. As a form of economic development, art is more and more popular among people. Art economy is not only characterized by high additional value, but also is an environmentally friendly and sustainable economic development pattern. As an important form of art, music not only concerns cultural soft power of China, but also provides a new development direction for the transformation of its economic development pattern.

\section{Specify objectives and requirements of training of applied talents majoring in music in local} undergraduate schools

During the training of students majoring in music in local undergraduate schools, it is required to first specify training objectives and then establish a scientific training mode of applied talents according to training objectives. When objectives are established, it is necessary to make corresponding reforms according to students' characteristics.

\section{Students should first possess the most basic ideological and moral quality}

Art is borderless, but artists have national boundaries. In the process of training music students, it is necessary to first make students possess high ideological and moral quality and corresponding sense of social responsibility and good moral quality in their future work. ${ }^{[2]}$

\section{Students should master knowledge and skills of music major}

For students majoring in music, the main objective of learning is to make themselves master music knowledge better and complete music learning tasks. In the process of learning music knowledge, students should master some most basic musical instruments besides the most basic music knowledge. In addition, students majoring in music should understand the development state of music in foreign countries in time and have broad knowledge and music view in the learning process. Meanwhile, they should also train their abilities of music aesthetics and appreciation and the corresponding ability of music creation if conditions are possessed. 


\section{Skill requirements except professional knowledge}

In the training of applied talents majoring in music in local undergraduate schools, students should master some knowledge besides professional knowledge of specialized courses. Besides the learning of specialized courses, students majoring in music should also possess skills of at least one foreign language. Music is borderless. It is a tool for the communication of people. Therefore, only by mastering a foreign language can music students understand the develop state of music in other countries and perform the music of other countries in future performance. In addition, students majoring in music should possess the corresponding knowledge of computer. The current society is the times with great prosperity of informatization. Computer has become an indispensable tool in our life. Therefore, students majoring in music should possess corresponding computer skills.

\section{Establish educational pattern of applied talents with the training of students' abilities as objective}

\section{Basic meaning of applied talents}

Just as the name implies, applied talents refer to talents trained based on social demand. ${ }^{[3]}$ Applied talents and some specialized research talents have great differences. Applied talents have strong ability of social practice and can enter social production and work in time. However, different from specialized professional technical talents, applied talents have certain theoretical accomplishment. Therefore, they are comprehensive talents with both theoretical accomplishment and practical skills. Applied talents are very common in the construction of social economy, such as lawyer, accountant and doctor. Economic foundation determines superstructure. The generation of applied talents originates from large social demand. In the development history of Chinese applied talents, the training of the earliest applied talents can be traced back to Westernization Movement period advertising “learning from foreigners to competing foreigners”. At that time, Qing Government set up a large batch of schools for training translation talents such as School of Combined Learning in order to learn western technologies. With the constant development of the times, huge demands for applied talents occur again in the socialist modernization construction in China.

\section{Establish training mode of applied talents majoring in music in local undergraduate schools}

With the proposal of the strategy for establishing "powerful country in culture", China has constantly increasing demands for applied technical talents majoring in music. To respond to the great strategy of China for establishing "powerful country in culture", the music major of some local undergraduate schools starts to explore a training mode of applied talents meeting social demands. ${ }^{[4]}$ As a form of art, music has strong infection, spreading capacity and public participation. Therefore, music is not only a form of art, but also a link for communication among people. People of different races in different countries can communicate through music. Meanwhile, music presents the image and spiritual outlook of a country to the world. Therefore, local undergraduate schools must have full understanding of music connotations, features and functions and make applied talent training mode established give full play to music functions according to music features in the establishment of applied talents majoring in music. Meanwhile, they should also consider features and acceptance capability of students and social needs during the training of applied music talents so as to make applied talent training mode more scientific.

\section{Implement applied talent training direction with course system as construction center}

For teaching, course system divides teaching tasks of a course into specific teaching contents of a class, implement teaching tasks and gradually realize teaching objectives through teaching contents of each class. Therefore, the establishment of course system plays a key role in the training of students' abilities. Therefore, local undergraduate schools must form their own school-running concept and characteristics and put emphasis on the development of students' abilities in the establishment of classroom system. 


\section{Keep close contact with actuality and establish course system of applied talents}

In China, the teaching of specialized talents majoring in music has started late. Therefore, music major in some undergraduate schools in China, especially some newly founded undergraduate schools, has run for a short time and lacks teaching experience. In addition, due to the lack of corresponding importance attached to the teaching of music major in traditional concept, funds for music teaching in newly founded undergraduate schools are relatively lacking. Moreover, due to the lack of professional talents of music teaching in China, teacher resources of music teaching cannot meet teaching demands of undergraduate schools. Under the influence of traditional concept, there are small social demands for music talents and students often choose popular programs with easy employment. Therefore, students majoring in music often do not have a good quality. During the establishment of course system of applied talents majoring in music, it is required to establish a scientific course system according to existing teacher resources in undergraduate schools and students' actual acceptance capability and consider both the development ability of schools and the learning ability of students.

\section{Adjust the proportion of required courses and optional courses appropriately}

Course structure plays an important role in the transformation of course contents into teaching practice. If the course structure is unreasonable, students might be too strong in some aspect, but their abilities in other aspects cannot be exercised correspondingly. Therefore, to train scientific talents majoring in music, it is necessary to establish a reasonable course structure. Main contents of the course structure include the proportion of optional courses and required courses and the proportion of theory courses and practice courses. According to training mode of applied talents, local undergraduate schools should establish a course structure suitable for students' development according to their acceptance capability. In addition, schools should adjust course structure correspondingly in different teaching stages and adjust courses for students majoring in music scientifically by merging and transforming courses. For example, schools should pay more attention to theory teaching of music major during the establishment of courses in freshman teaching stage. After students enter senior grades, schools should train the practical ability of students appropriately. In a word, the setting of course structure is not changeless during the teaching of students majoring in music. It is necessary to make corresponding adjustments according to teaching contents and students' actual acceptance capability.

\section{Build excellent courses}

In music teaching, excellent courses have their unique value and significance. They not only reflect school-running features of a school, but also play an important demonstration role in the teaching reform of music major. In addition, excellent courses can facilitate the construction of teaching staff. In a word, they play a vital role in the improvement of teaching quality of music major. Therefore, it is required to set up relevant excellent course education in music teaching of local undergraduate schools. In the establishment process of excellent courses, local undergraduate schools should form their unique style of excellent courses according to features of music major and school-running focus. Moreover, it is required to absorb students actively in the establishment of excellent courses of music and listen to students' opinions and suggestions, thus making excellent courses have high teaching value and applicability for students.

\section{Use teaching materials suitable for music major}

Teaching material is an important constituent part in the establishment process of teaching courses. Teaching material is not only teaching basis of teachers, but also an important tool of learning. Good teaching materials can not only improve students' interest in learning, but also allow students to grasp solid knowledge. In the procurement process of teaching materials, teaching material procurement department must buy teaching materials actually required by each major according to teaching actuality of each major. During the procurement of teaching material, it is required to seek for opinions of teachers of each specialized course and buy teaching materials according to teachers' 
teaching actuality. In addition, undergraduate schools should establish a specialized teaching material evaluation and management system and allow teaching materials to make corresponding adjustments according to constant development of the society and have strong social adaptiveness.

\section{Pay attention to practical teaching in the establishment of training mode of applied talents}

Applied talents have not only corresponding theoretical knowledge, but also corresponding practical ability of music. ${ }^{[5]}$ Therefore, more attention should be paid to practical teaching in the training of applied talents majoring in music. In music teaching, practical teaching includes many types. The primary form of practical teaching is performance rehearsal of students. Students' practical ability is exercised through a series of performance. Moreover, on-campus and off-campus communication can provide students with more performance opportunities and exercise their performance abilities during performance. In practical teaching of music, teachers should correct students' deficiencies in time during their performance, affirm students' merit and create appropriate music practical ability for students according to their voice features and performance ability.

\section{Conclusion}

Music is not only a form of art, but also the representative and symbol of a country. With the constant progress of the times, people have higher and higher pursuit for living standard. They not only pursue for physical enjoyment, but also pay more attention to the pursuit for spiritual life. Therefore, to satisfy social demands for music and improve cultural soft power of China, music major of undergraduate schools should explore applied music talents suitable for realistic development needs and train appropriate talents for the establishment of strategy of "powerful country in culture" in the process of music teaching.

\section{References}

[1] Cheng Yan. Research on Establishment of Strategies for Training Applied Talents Majoring in Music in Undergraduate Schools. Sichuan Drama, 2013(3):141-143.

[2] Liu Wei. Research on Training of Applied Talents Majoring in Normal Music in Undergraduate Schools in Hebei. Hebei Normal University, 2011.

[3] Liu Xinjie, Zhou Yong. Research on Theory and Practice of Contemporary Interdisciplinary Talent Training Mode - Take Applied Talent Training of College Students Majoring in Music in Undergraduate Schools for Example. Notonly Music, 2014(5):10-11.

[4] Chen Lingling. Problems Existing in Practical Teaching of Music Major in Applied Undergraduate Schools and Countermeasures. Education of Guangxi C (Profession and Higher Education Edition), 2013(12):18-19.

[5] Tang Haiyan. Research and Practice of Training of Talents Majoring in Music Through University-Enterprise Cooperation in Local Undergraduate Schools. Northern Music, 2014(6):218-218,224. 